УДК 342.98

DOI https://doi.org/10.32837/apdp.v0i88.3067

M.І.Смокович

\title{
ПРИНЦИП ПРАВОВОЇ ВИЗНАЧЕНОСТІ В АДМІНІСТРАТИВНОМУ СУДОЧИНСТВІ: ОКРЕМІ ТЕОРЕТИЧНІ ЗАСАДИ ТА ПРАКТИЧНЕ ЗАСТОСУВАННЯ
}

Одним з основних засад справедливого судочинства вважається принцип верховенства права. Якщо звернутися до витоків вказаного принципу, доцільно згадати, що сучасне розуміння поняття «верховенство права» запровадив професор А.В. Дайсі - відомий британський правник-конституціоналіст, який у своїй праці "Introduction to the Study of the Law of the Constitution" (1885 р.) запропонував концепцію, однією із провідних ідей якої була теза, що жодна людина не може зазнавати покарання, окрім як у разі явного порушення закону, який повинен забезпечувати визначеність та передбачуваність, щоб ним могли керуватись громадяни під час учинення дій чи ведення справ, і який не повинен дозволяти карати особу ретроспективно [1].

Розуміння верховенства права як формальної законності є домінантним для лібералізму і капіталізму і найбільш поширене серед теоретиків права. Його найважливішою рисою є передбачуваність [2, с. 138].

Саме передбачуваність є основою одного з фундаментальних, основоположних для реалізації захисту прав та інтересів кожної особи - принципу правової визначеності, який, у свою чергу, є однією зі складових частин принципу верховенства права, керівною засадою під час здійснення адміністративними органами своїх владних обов'язків та повноважень.

У демократичному суспільстві правова визначеність визнається однією з основоположних цінностей, це саме той принцип, який покликаний надати можливість учасникам правовідносин передбачити результати своїх дій, водночас передбачає і прогнозованість судових рішень за результатами розгляду спорів. Більшість дослідників визначають принцип правової визначеності як сукупність вимог до організації та функціонування правової системи з метою забезпечення стабільного правового становища особи шляхом удосконалення процесів як правотворчості, так і правозастосування.

Вимога визначеності - одна з найсуттєвіших, що висуваються як до правових актів, так і до судових вердиктів. Правова визначеність як елемент верховенства права постулюється в таких проявах, як: непорушність і нескасовуваність набутих законних прав (vested rights); законні очікування (legitimate expectations) - право особи розраховувати на сталість законодавства; незворотність закону й неможливість застосування закону до особи, яка не могла знати про його існування (nonretroactivity) [3, c. $130 ; 4$, с. 153].

Головним аспектом принципу правової визначеності є визначеність норми, яка становить неодмінну властивість права. Визначеність процесу створення 
та застосування правових норм забезпечує чіткість і злагодженість діяльності відповідних юридичних механізмів. Норма права постулюється як загальнообов'язкове формальне правило належної поведінки, що встановлюється та забезпечується державою, закріплене й оприлюднене в офіційних актах, спрямоване на регулювання суспільних відносин шляхом визначення прав і обов'язків їхніх учасників [5, с. 159].

Принцип правової визначеності бере свій початок ще до появи римського та давньогрецького законодавства. Коли тиранія була переможена, а закони почали ухвалювати на народних зборах, тоді вони набули демократичного «забарвлення». $\mathrm{y}$ той же час виникла проблема, яка свідчила, що норми, хоча й були чітко визначені, зрозумілі, але могли бути замінені іншими законами. Надалі цей принцип був відображений у різних джерелах, серед яких: Велика хартія вольностей (1215р.), Декларація прав людини і громадянина (1989р.), Конституціях прав і вольностей Війська Запорозького (1710 р.) тощо.

Звісно, важливу роль у розкритті принципу правової визначеності відіграв Європейський суд з прав людини (далі - ЄСПЛ), що у своїй практиці часто наголошує на важливості цього принципу. Коли знаходимо витоки походження цього принципу, бачимо, що європейський принцип правової визначеності походить від німецького принципу Rechtssicherheit (дослівно - «правова безпека»), метою якого $€$ забезпечення чіткості змісту законодавства, який переважно застосовується у справах щодо ретроактивної дії законодавства; принцип захисту законних очікувань походить від німецького Vertrauensschutz (дослівно - «захист довіри»), метою якого є забезпечення того, щоби кожен, хто має довіру до легальності рішень і дій публічної адміністрації, підлягав захисту [6, с. 320-341].

Цей принцип знаходить своє відображення у джерелах права Європейського Союзу (далі - ЄС) і застосовується у практиці ЄСПЛ, є спільним для правопорядків держав - членів СС, набуває поширення у праві України. Окремі науковці пропонують розглядати принцип правової визначеності як сукупність вимог до організації та функціонування правової системи з метою забезпечення насамперед стабільного правового становища індивіда шляхом удосконалення процесів правотворчості та правозастосування [7, с. 54].

Загалом, позиція щодо віднесення цього принципу до складових частин верховенства права була запропонована Ф. Гайєком, який зазначив, що верховенство права передбачає, що органи державної влади повинні бути обмежені у своїх діях заздалегідь встановленими й оголошеними правилами, які дають можливість передбачити з великою точністю примусові заходи, що будуть застосовані представниками влади в тій чи іншій ситуації [8, с. 90].

У свою чергу, коли говоримо про структуру принципу правової визначеності, то варто зробити висновок, що зміст принципу правової визначеності включає такі положення, як: нечинність акта, який не був належним чином опублікований; відсутність зворотної сили акта, що означає неможливість застосування акта до ситуацій, які виникли до набрання ним чинності; виправдані очікування, що передбачає можливість внесення змін до правових актів після попереднього оповіщення тих, кому нові правила адресовані; ясність і зрозумілість права [9, с. 60]. 
Нині маємо констатувати, що наше національне правосуддя ще перебуває на шляху до впровадження загальноприйнятних європейських критеріїв справедливого судочинства. Проте прогрес відбувається, його можна простежити навіть у рішеннях Європейського суду з прав людини щодо порушення ст. 6 Конвенції під час здійснення судочинства. Варто звернути увагу на те, що рішення ЄСПЛ регулюють відносини та роз'яснюють ті правові позиції, які недостатньо врегульовані національним законодавством. Вони дають можливість ухвалити рішення з урахуванням більш чіткого розуміння права особи на захист, права учасників на розумні строки розгляду справи в суді тощо. Усе це в сукупності справді посилює правову систему України та сприяє справедливому розгляду справ у суді $[10$, с. 49$]$.

Принцип правової визначеності узагальнюе такі загальноправові категорії, як «непорушність прав», «якість та точність закону», «стабільність та остаточність судових рішень», «законні очікування», на які спирається практика Європейського суду з прав людини, як і практика Верховного Суду. Зокрема, Європейський суд у своїх рішеннях («Брумареску проти Румунії», «Стіл та інші проти Сполученого Королівства» тощо) неодноразово робив висновок, що принцип правової визначеності є одним із фундаментальних аспектів верховенства права.

Якщо коротко розкрити кожну з наведених категорій, доречно вказати, що непорушність гарантованих прав та свобод людини закріплена на рівні Основного закону - Конституції України, відповідно до положень якої права і свободи людини є невідчужуваними та непорушними (ст. 21); конституційні права і свободи людини не є вичерпними, гарантуються і не можуть бути скасовані (ст. 22); конституційні права і свободи людини не можуть бути обмежені, крім випадків, передбачених Конституцією України (ст. 64).

Венеціанська комісія у своїй доповіді від 4 квітня 2011 р. «Верховенство права» вказала, що правова визначеність є елементом верховенства права та є істотно важливою для питання довіри до судової системи. Щоби досягти цієї довіри, держава повинна зробити текст закону легкодоступним, закон має бути сформульований із достатньою мірою чіткості, щоби особа мала можливість скерувати свою поведінку. Водночас у рішенні у справі «Ольссон проти Швеції» (“Olsson v. Sweden”, 24 March 1988) ЄСПЛ зазначив, що норма національного закону не може розглядатися як право, якщо її не сформульовано з достатньою точністю так, щоб громадянин мав змогу, якщо потрібно, з відповідними рекомендаціями, деякою мірою передбачити наслідки своєї поведінки.

Окрім того, Європейський суд зазначає, що «якість закону» означає, що національне законодавство повинне бути доступним і передбачуваним, тобто визначати досить чіткі положення, щоби дати людям адекватну вказівку щодо обставин і умов, за яких державні органи мають право вживати заходів, що вплинуть на права осіб (рішення у справах «Олександр Волков проти України», “C.G. та інші проти Болгарії, тощо). Відповідальність за подолання недоліків законодавства, правових колізій, прогалин, інтерпретаційних сумнівів лежить, серед іншого, і на судових органах, які застосовують та тлумачать закони (рішення у справах «Вєренцов проти України», «Кантоні проти Франції»). 
Для забезпечення дотримання принципу передбачуваності, як зауважує Венеційська комісія, закон має бути, за можливості, проголошений наперед - до його застосування, має бути передбачуваним щодо його наслідків. Коли особа переконана в досягненні запланованого результату, має легітимні (законні) очікування, діє згідно з нормами права, їй має бути гарантований захист цих очікувань. Близькою до окресленого принципу є презумпція незворотності дії закону в часі й неможливості застосування закону до особи, яка не могла знати про його існування.

Практика Верховного Суду є особливо показовою щодо дотримання правової визначеності. Як зазначає Європейський суд, якщо конфліктна практика розвивається в межах одного з найвищих судових органів країни, цей суд сам стає джерелом правової невизначеності, тим самим підриває принцип правової визначеності та послаблює довіру громадськості до судової системи (рішення у справі «Парафія Греко-католицької церкви у м. Люпені проти Румунії»). Тобто необхідно уникати суперечливостей у судовій практиці [11].

Доречною для опису принципу правової визначеності є цитата Л. Богачової: «Правова визначеність є універсальним правовим началом, дія якого поширюється на такі важливі сфери правовідносини між державою і особою, як реалізація та забезпечення прав і свобод людини і громадянина, встановлення юридичної відповідальності, підстав та порядку притягнення до неї, недопустимість дій та бездіяльності, спрямованих на безпідставне обмеження прав і свобод людини, встановлення пропорційності застосованих до особи обмежень, здійснення повноважень органами державної влади в межах, визначених Конституцією і законами України» [12].

Якщо зробити проміжний висновок, то варто вказати, що принцип правової визначеності вимагає дотримання таких вимог:

1. Будь-яка правова норма повинна бути офіційно оприлюднена, у порядку, затвердженому законодавством, тобто має бути простою для ознайомлення. Держава повинна вжити всіх можливих заходів, що необхідні для того, щоб довести до відома своїх громадян. Отже, державні органи зобов'язані забезпечити доступність закону і можливість громадянам орієнтуватися в тому, до якого саме правового випадку застосовується ухвалена норма.

2. Зміст правової норми повинен відповідати законним очікуванням особи, щоб особа могла усвідомлювати наслідки своїх дій і оцінювати свої дії з позиції законності. Для розкриття цієї вимоги вважаю необхідним зазначити, що важлива підтримка стабільності законодавства. Це означає, що не можуть бути допущені непередбачувані зміни в чинних нормах, бо закон має бути стабільним. Жодна норма не повинна дезорієнтувати суб'єкта, щоби будь-які суспільні відносини встигали адаптуватися до нових законодавчих умов. Щодо цієї вимоги є декілька рішень ЄСПЛ, зокрема, у цьому контексті хочу згадати справу «Свято-Михайлівська парафія проти України». У цій справі Суд додержується думки, що ця вимога повинна детально прописати перелік причин та підстав для відмови в реєстрації та внесенні змін у статути релігійних об'єднань. Суд уважає, що ця вимога зобов'язувала державу-відповідача законодавчо передбачити детальний перелік можливих причин та підстав для відмови в реєстрації змін та доповнень до статутів релігійних 
об’єднань. Національне законодавство передбачило лише одну підставу для такої відмови, на мій погляд, дуже нечітку, а саме, якщо «статут релігійної громади або їі діяльність суперечать чинному законодавству», зокрема, це зазначено в ч. 2 ст. 15 Закону України «Про свободу совісті та релігійні організації». Закон передбачає необхідність обгрунтувати відмову, але жодна його стаття не уточнює, наскільки чітким таке обгрунтування має бути, чого саме воно повинно стосуватися (наприклад, невідповідності тексту статуту певним нормам, його цілей тощо). Тобто Суд не певний, що ця норма надавала достатньо гарантій проти свавілля суб'єктів владних повноважень, що відповідають за реєстрацію релігійних об'єднань. Також доцільно вказати, що стабільність є важливою для законодавства, але це не повинно означати незмінюваності законодавства взагалі, тому що держава розвивається, утворюються нові інституції, які потребують правового регулювання. Має бути наявна гнучкість правових норм, що є однією з ознак їхньої ефективності.

3. Звісно, важливі логічність та чіткість тексту закону, бо для сприйняття норми є обов'язковими однозначність, зрозумілість, відносна конкретність норми, тому що саме це є запорукою належного тлумачення, що сприяє ефективній реалізації норми. Доречним, на мій погляд, буде звернення до висновку Свропейського суду, у якому зазначено: "Норма не може розглядатися як «право», якщо її не сформульовано з достатньою точністю так, щоб громадянин мав змогу, якщо потрібно, з відповідними рекомендаціями, до певної міри передбачити наслідки, що ії може мати вчинена дія» (“Olsson v. Sweden (№ 1)”, № 10465/83, 24 March 1988). Справді, однозначність та конкретність будь-якої норми важливі для правильного сприйняття та тлумачення.

4. Визначеність меж дискреційних повноважень органів державної влади. ЄСПЛ щодо цього наголошує : «Закон, який надає дискрецію, не є сам собою несумісним із вимогою передбачуваності в тому разі, коли обсяг дискреції та спосіб її застосування зазначені з достатньою чіткістю та водночас ураховується легітимна мета того чи іншого вживаного заходу в тій чи іншій ситуації, щоб надати індивіду адекватний захист від свавільного втручання» (“Olsson v. Sweden (№ 1)”, № 10465/83, $24 \mathrm{March} \mathrm{1988).} \mathrm{Тобто} \mathrm{дискрецію} \mathrm{потрібно} \mathrm{сприймати} \mathrm{із} \mathrm{застереженням,} \mathrm{що} \mathrm{її} \mathrm{варто}$ обмежувати законом та іншими елементами верховенства права, наприклад, забезпечення кожному доступу до безстороннього, справедливого суду шляхом застосування правових норм однаково до всіх і у спосіб, де відсутня свавільність.

5. Спеціальний дозвільний характер правового регулювання діяльності адміністративних органів. Це означає, що особа може вчиняти дії, які не заборонені законом, а органи влади виконують лише ті дії, що прямо передбачені законом.

6. Крім того, професор М. Козюбра, з яким я погоджуюся, виділяє також вимогу до принципу правової визначеності - винятково законодавче закріплення повноважень органів влади. Також вказує, що це є і гарантією запобігання зловживанням владними повноваженнями органами влади, чітких встановлених обов'язків будьякого адміністративного органу, щоб існував зрозумілий порядок проведення будьякої процедури як для суб'єкта владних повноважень, так і для громадянина [13].

Отже, стосовно норм, які визначають компетенцію державних органів, діють додаткові вимоги заборони широких дискреційних повноважень. Процедурні 
вимоги включають: обов'язкове оприлюднення нормативно-правових актів, заборону їх зворотної сили, розумну стабільність права, послідовність правотворчості, надання достатнього часу для змін у системі правовідносин, зумовлених ухваленням нового закону.

У правозастосуванні принцип правової визначеності вимагає, щоб нормативно-правові акти дотримувалися; існувала практика уточнення (конкретизації) змісту нормативно-правових актів; практикувалося одноманітне застосування закону; рішення судів щодо застосування закону були остаточними й обов'язковими.

Підбиваючи підсумки, потрібно зазначити, що теоретичні засади принципу правової визначеності мають практичне значення в усіх сферах, не викликає сумнівів, що цей принцип має особливе значення, зокрема й для адміністративних процедур.

Так, адміністративні органи повинні чітко і доступно формулювати свої рішення, пояснювати умови адміністративних процедур, водночас чітко дотримуватись усіх вимог законодавства, давати можливість особам реалізувати та захистити свої права, інтереси й обов'язки.

Зокрема, принцип правової визначеності спрямований на те, щоби зробити взаємодію держави та громадян ефективною, доступною та легкою. На мій погляд, реалізація цього принципу в усіх сферах є однією з найголовніших умов для побудови європейської демократичної держави.

Нині в Україні наявні деякі складнощі в реалізації принципу правової визначеності в адміністративних процедурах. Так, хочу навести приклад спору, щодо якого Суд у своєму рішенні дійшов висновку, що принцип правової визначеності був порушений (справа № 815/2827/18).

Отже, до Одеського окружного адміністративного суду надійшов позов особи до Головного управління державної міграційної служби (далі - ГУ ДМС) України в Одеській області про визнання протиправними дії ГУ ДМС України в Одеської області щодо відмови у зміні посвідки на постійне проживання в Україні, яка була пошкоджена.

Так, у 2018 р. громадянин В'єтнаму (позивач) звернувся до відділу ГУ ДМС України в Одеській області із клопотанням щодо обміну наявної в нього посвідки на постійне проживання в Україні, яка була йому видана уповноваженим органом у 2010 р., у зв’язку з тим, що його посвідка була випадково пошкоджена. Для цієї процедури він надав усі необхідні документи, але рішення суб'єктом владних повноважень щодо заміни йому пошкодженої посвідки на посвідку нового зразка ухвалене не було. Навіть більше, позивачеві було скасовано дозвіл на отримання посвідки на постійне проживання в Україні.

Отже, позивач уважав, що його права й інтереси були порушені відповідачем, а саме не замінено посвідку, зважаючи на положення Кодексу адміністративного судочинства (далі - КАС) України, із чим і звернувся до Одеського окружного адміністративного суду.

Очевидно, що відповідно до Конституції України, органи державної влади й органи місцевого самоврядування, їх посадові особи зобов'язані діяти лише на підставі, у межах повноважень та у спосіб, що передбачені Конституцією та законами України. 
Згідно з нормами КАС України, у справах щодо оскарження рішень, дій чи бездіяльності суб'єктів владних повноважень адміністративні суди перевіряють, чи ухвалені вони на підставі, у межах повноважень та у спосіб, що передбачені Конституцією та законами України; обґрунтовано, тобто з урахуванням усіх обставин, що мають значення для ухвалення рішення (учинення дії); безсторонньо (неупереджено); добросовісно; розсудливо; з дотриманням принципу рівності перед законом, запобігаючи всім формам дискримінації; пропорційно, з дотриманням необхідного балансу між будь-якими несприятливими наслідками для прав, свобод та інтересів особи і цілями, на досягнення яких спрямоване це рішення; з урахуванням права особи на участь у процесі ухвалення рішення; своєчасно, тобто протягом розумного строку.

Під час розгляду справи було встановлено, що в 1988 р. позивач, відповідно до наданою інформації, разом зі своєю дружиною, яка також є громадянкою В'єтнаму, прибули до України (тоді - до Української Радянської Соціалістичної Республіки) за міжурядовою угодою (між урядом Радянського Союзу та В'єтнамом) «щодо працевлаштування громадян В'єтнаму на підприємствах у СРСР».

Позивач працював у 1988-1993 pp. за контрактом і проживав на території України. У 2002 р. позивач звернувся до відповідного органу для отримання дозволу на імміграцію в Україну, дозвіл був отриманий, а разом із ним і посвідка на постійне проживання в Україні.

Далі в позивача та його дружини народилася дитина, потім і друга. Позивач став на облік платників податків України, отримав посвідчення водія. Що свідчить про те, що позивач працює та законно сплачує податки в Україні. Діти позивача отримали паспорти України, старша донька стала студенткою Національного університету, родиною були придбано власне житло в Україні. У 2010 р. позивачу було змінено посвідку старого зразка на посвідку нового зразка.

Отже родина постійно проживала на території України, родина росла, старша донька народила онука. Тобто позивач підтвердив, що фактично проживає в Україні майже 30 років та періодично звертався до ВГІРФО ГУМВС України в Одеської області щодо отримання та заміни посвідки на постійне проживання, із чого можна зробити висновок, що позивач перебуває в Україні на законних підставах.

Підсумуємо. Суд з’ясував усі обставини справи, проаналізував надану позивачем інформацію та дійшов висновку, що підстав для скасування дозволу на отримання посвідки на постійне проживання в Україні виявлено не було. Важливим фактом є те, що у 2010 р. позивачу було змінено посвідку старого зразка, оформлено та видано нову посвідку на постійне проживання, у якій містилися позначка про безстроковий термін ï дії: вона підлягає обміну тільки в разі досягнення особою 25 -ти і 45 -ти річного віку.

Відповідно до Порядку № 251, усі документи, зазначені в цьому документі, були подані позивачем із дотриманням усіх умов для отримання посвідки. У зв'язку із цим Суд дійшов висновку, що відповідачем протиправно вчинено бездіяльність у нездійсненні обміну посвідки на постійне проживання в Україні у зв'язку з їі пошкодженням. 
Також Суд зазначив, що з моменту отримання позивачем посвідки на постійне проживання минуло 16 років, у позивача сформувався певний уклад життя, виникли зв' язки з оточенням. Позивач разом із родиною проживає в місті Одесі, має двох дітей та онука, які народились в Україні та мають громадянство України. Отже, з боку позивача порушення законодавства про імміграцію відсутні, а фактично порушень припустився державний орган, який не здійснив обміну позивачу посвідки на постійне проживання в Україні за спливом встановленого Законом строку.

Суд спирався на рішення ЄСПЛ у справі "Yvonne van Duyn v. Home Office" (Case 41/74 van Duyn v. Home Office), де зазначено, що принцип юридичної визначеності означає, що зацікавлені особи повинні мати змогу покладатися на зобов'язання, взяті державою, навіть якщо такі зобов'язання містяться в законодавчому акті, який загалом не має автоматичної прямої дії. Така дія зазначеного принципу пов'язана з іншим принципом - відповідальності держави, який полягає в тому, що держава не може посилатися на власне порушення зобов'язань для запобігання відповідальності. Суд дійшов висновку, що відповідачем не було доведено «легітимної мети», тобто будь-яке обмеження чи відмова повинні бути «необхідними» у демократичному суспільстві.

Отже, Суду необхідно було проаналізувати, перевірити, чи було таке обмеження виправдано, необхідним, важливим у такому демократичному суспільстві, оцінити пропорційність рішення державного органу тощо. Щодо цього важливим є рішення у справі «Ляшко проти України» (“Lyashko v. Ukraine”) від 10 серпня 2006 р. (заява № 21040/02, п. 47).

Проведений аналіз матеріалів справи та з'ясування, чи належним чином національні органи влади використали свою свободу повноважень, дали підстави для того, щоби Суд дійшов висновку, що ухвалене щодо позивача рішення суб'єкта владних повноважень не було необхідним, а баланс між будь-якими несприятливими наслідками для прав, свобод та інтересів особи і цілями, на досягнення яких спрямоване це рішення, має бути дотриманий.

Суд підкреслив порушення відповідачем принципу правової визначеності та зазначив, що така бездіяльність відповідача порушила права й інтереси не тільки позивача, але і його дітей, які є законними громадянами України.

Звісно, принцип правової визначеності безпосередньо не закріплений у національному законодавстві, але його значущість для результативного правового регулювання підтверджується практикою Конституційного Суду України.

М. Гультай вивчає питання реалізації принципу правової визначеності в рішеннях Конституційного Суду України та зазначає, що наявний стійкий зв'язок між принципом правової визначеності і дотриманням прав, інтересів людини, громадянина, а зв'язок із такою правовою категорією, як стабільність, верховенство права. Також науковець наголосив, що правова визначеність - універсальне правове начало, його дія поширюється на сфери правовідносин між державою й особою, як забезпечення прав і свобод людини і громадянина, встановлення юридичної відповідальності, недопустимість дій та бездіяльності, спрямованих на безпідставне обмеження прав і свобод людини, встановлення пропорційності застосованих до особи обмежень, здійснення повноважень органами державної влади [14, с. 93]. 
Конституційний Суд України сформулював власне бачення правової визначеності. Так, у рішенні від 22 вересня 2005 р. № 5-рп/2005 у справі про постійне користування земельними ділянками зазначається, що «із конституційних принципів рівності і справедливості випливає вимога визначеності, ясності і недвозначності правової норми, оскільки інше не може забезпечити ії однакове застосування, не виключає необмеженості трактування у правозастосовній практиці і неминуче призводить до сваволі» (абз. 2 пп. 5.4 п. 5 мотивувальної частини). Цим Конституційний Суд України наголосив, що невизначеність, нечіткість правової норми призводять до її неоднакового розуміння та тлумачення, що у практичній площині зумовлює різне застосування. Така неврегульованість чи відсутність визначеності в діяльності органів державної влади щодо особи, зокрема забезпечення, додержання чи реалізації прав і свобод людини і громадянина, може мати негативні наслідки і призвести до сваволі. Визначеність правового регулювання має на меті запобігання будь-якому її прояву щодо особи [15].

Венеціанська комісія також підтримує позицію Конституційного Суду України та у своїй доповіді закріпила, що верховенству права суперечив би такий стан, за якого юридична свобода розсуду виконавчої влади надавалася б необмежено. Отже, у законі має бути визначена сфера будь-яких форм розсуду і те, як така свобода повинна здійснюватися, причому це має бути досить ясним, щоб окрема особа була належним чином захищена від сваволі (п. 45) [16].

У рішенні від 29 червня 2010 р. № 17-рп/2010 Конституційний Суд України звернув увагу на правову визначеність як елемент верховенства права: «Одним з елементів верховенства права є принцип правової визначеності, у якому стверджується, що обмеження основних прав людини та громадянина і втілення цих обмежень на практиці допустиме лише за умови забезпечення передбачуваності застосування правових норм, встановлюваних такими обмеженнями. Тобто обмеження будь-якого права повинне базуватися на критеріях, які дадуть змогу особі відокремлювати правомірну поведінку від протиправної, передбачати юридичні наслідки своєї поведінки» (абз. 3 пп. 3.1 п. 3 мотивувальної частини) [17]. Цим Конституційний Суд України наголосив, що правовій визначеності відповідатиме встановлення обмежень основних прав людини і громадянина лише за умови забезпечення зрозумілих і передбачуваних для особи наслідків застосування правових норм. Конституційний Суд України застосовує правову визначеність також у справах, що стосуються повноважень органів державної влади.

У рішенні від 1 квітня 2008 р. № 4-рп/2008 у справі про Регламент Верховної Ради України Конституційний Суд України послався на те, що «поділ державної влади є структурною диференціацією трьох рівнозначних основних функцій держави: законодавчої, виконавчої, судової. Він відображає функціональну визначеність кожного з державних органів, передбачає не тільки розмежування їхніх повноважень, а й їх взаємодію, систему взаємних стримувань та противаг, які мають на меті забезпечення їх співробітництва як єдиної державної влади. Неухильне додержання органами законодавчої, виконавчої та судової влади Конституції та законів України забезпечує реалізацію принципу поділу влади і є запорукою їхньої єдності, важливою передумовою стабільності, підтримання громад- 
ського миру і злагоди в державі» (абз. 2, 4 пп. 4.1 п. 4 мотивувальної частини) [18]. Цими правовими позиціями Конституційний Суд України підтвердив зв'язок принципу поділу влади та принципу правової визначеності, який полягає у визначеності органів законодавчої, виконавчої і судової влади, розмежуванні їхніх повноважень та взаємодії цих органів, що сприяє стабільності, підтриманню громадського миру, безпеки і злагоди в державі.

У рішенні від 11 березня 2010 р. № 8-рп/20101 Конституційний Суд України зазначив, що наявність двох касаційних інстанцій для перевірки рішень спеціалізованих судів не відповідає засадам правової визначеності (абз. 3 пп. 3.4 п. 3 мотивувальної частини) [19].

Правова визначеність є універсальним правовим началом, дія якого поширюється на такі важливі сфери правовідносини між державою і особою, як реалізація та забезпечення прав і свобод людини і громадянина, встановлення юридичної відповідальності, підстав та порядку притягнення до неї, недопустимість дій та бездіяльності, спрямованих на безпідставне обмеження прав і свобод людини, встановлення пропорційності застосованих до особи обмежень, здійснення повноважень органами державної влади в межах, визначених Конституцією і законами України.

Принцип правової визначеності є одним з основних принципів, на якому базується будь-яке демократичне утворення. Принцип правової визначеності передбачає наявність злагодженого механізму, здатного забезпечувати верховенство права та слугувати стандартом для законодавства та судочинства [20]. Дотримання вимог принципу правової визначеності наблизить українське законодавство до європейських правових стандартів, сприятиме вдосконаленню механізмів правотворчості та правореалізації, слугуватиме додатковою гарантією захищеності людини від свавілля органів державної влади [12].

\section{Jimepamypa}

1. Disay A. Introduction to the Study of the Law of the Constitution. URL: http://files. libertyfund. org/files/1714/0125_Bk.pdf (дата звернення: 03.11.2020).

2. Таманага Б. Верховенство права : історія, політика, теорія. Перекл. 3 англ. А. Іщенка. Київ : Вид. дім «Києво-Могилянська академія», 2007. 208 с.

3. Магрело М. Концепт «законних очікувань» і принцип юридичної визначеності: причинно-наслідковий чи симбіотичний зв'язок? Наукові записки Інституту законодавства Верховної Ради України. 2013. № 3. С. 127-135.

4. Матвєєва Ю. Принцип правової визначеності як один із аспектів верховенства права. Порівняльне правознавство: сучасний стан і перспективи розвитку : збірник статей. Київ, 2010. С. 153.

5. Шевчук С. Судова правотворчість: світовий досвід і перспективи в Україні. Київ : Реферат, 2007. $640 \mathrm{c}$.

6. Reynolds Paul. Legitimate Expectations and the Protection of Trust in Public Officials. Public Law. Vol. 2011. P. 330-352.

7. Приймак А. Принцип правової визначеності : поняття та окремі аспекти. Наукові записки національного університету «Києво-Могилянська академія». 2010. Т. 103 : Юридичні науки. С. 53-55.

8. Хайек Ф.А. фон. Право, законодательство и свобода: Современное понимание либеральных принципов справедливости и политики. Пер. с англ. Москва : ИРИСЭН, 2006. 644 с.

9. Право Європейського Союзу : підручник / за ред. В. Муравйова. Київ : Юрінком-Інтер, 2011. 704 с.

10. Драч I. Не можна заради єдиного викриття злочину спонукати особу до його вчинення. Українська Гельсинська спілка з прав людини “Precedent UA - 2015" : збірник виступів. Київ : КВІЦ, 2015. C. $49-52$. 
11. Огнев'юк Г. Обов'язковість рішення суду як складова принципу правової визначеності. Часопис Київського університету права. 2015. № 2. C. 172. URL: http://nbuv.gov.ua/UJRN/Chkup_2015_2_42 (дата звернення: 03.11.2020).

12. Богачова Л. Принцип правової визначеності в європейському і національному праві : змістова характеристика. Теорія і практика правознавства. 2013. Вип. 2. URL: http://nbuv.gov.ua/ j-pdf/ tipp_2013_2_74.pdf (дата звернення: 03.11.2020).

13. Козюбра М. Принцип верховенства права та вітчизняна теорія й практика. Українське право. 2006. № 1. С. 15-23.

14. Гультай М. Правова визначеність у рішеннях Конституційного Суду України. Вісник Конституиійного Суду України. 2012. № 5. С. 83-93.

15. Рішення у справі за конституційним поданням 51 народного депутата України щодо відповідності Конституції України (конституційності) положень ст. 92, п. 6 розд. X «Перехідні положення» Земельного кодексу України (справа про постійне користування земельними ділянками). Вісник Конституиійного Суду України. 2005. № 5. С. 19.

16. О верховенстве права. URL: http://www.venice.coe.int/docs/ 2011/CDL'AD (2011) 003rev'rus. pdf (дата звернення: 03.11.2020).

17. Рішення у справі за конституційним поданням Уповноваженого Верховної Ради України з прав людини щодо відповідності Конституції України Закону України «Про міліцію». Вісник Конституиійного Суду України. 2010. № 5. С. 11-17.

18. Рішення Конституційного Суду України у справі за конституційним поданням 50 народних депутатів України щодо відповідності Конституції України (конституційності) положень частин другої, третьої, четвертої статті 219 Регламенту Верховної Ради України від 1 квітня 2008 р. № 4-рп/2008. Вісник Конституиійного Суду України. 2008. № 2. С. 17.

19. Рішення у справі за конституційним поданням 46 народних депутатів України щодо офіційного тлумачення термінів «найвищий судовий орган», «вищий судовий орган», «Касаційне оскарження», які містяться у статтях 125, 129 Конституції України. Вісник Конституиійного Суду України. 2010. № 3. С. 12.

20. Матвєєва Ю. Юридико-технічні характеристики принципу правової визначеності. Наукові записки Національного університету «Києво-Могилянська академія». Серія «Юридичні науки». 2015. T. 168. C. $37-39$.

\section{Анотація}

Смокович М. I. Принцип правової визначеності в адміністративному судочинстві: окремі теоретичні засади та практичне застосування. - Стаття.

У статті досліджено окремі теоретичні засади та практичне застосування принципу правової визначеності в адміністративному судочинстві. Вказано, що принцип правової визначеності охоплює такі загальноправові категорії, як «непорушність прав», «якість та точність закону», «стабільність та остаточність судових рішень», «законні очікування», на які спирається практика Європейського суду з прав людини, як і практика Верховного Суду. Вказано, що саме передбачуваність є основою одного з фундаментальних, основоположних для реалізації захисту прав та інтересів кожної особи - принципу правової визначеності, який, у свою чергу, є однією зі складових частин принципу верховенства права, керівною засадою під час здійснення адміністративними органами своїх владних обов'язків та повноважень. Констатовано, що наше національне правосуддя ще перебуває на шляху до впровадження загальноприйнятних європейських критеріїв справедливого судочинства.

Зроблено висновок, що правова визначеність є універсальним правовим началом, дія якого поширюється на такі важливі сфери правовідносини між державою й особою, як реалізація та забезпечення прав і свобод людини і громадянина, встановлення юридичної відповідальності, підстав та порядку притягнення до неї, недопустимість дій та бездіяльності, спрямованих на безпідставне обмеження прав і свобод людини, встановлення пропорційності застосованих до особи обмежень, здійснення повноважень органами державної влади в межах, визначених Конституцією і законами України.

Констатовано, що принцип правової визначеності є одним з основних принципів європейського права і часто використовується у практиці Суду Європейського Союзу та Європейського суду з прав людини. У статусі загального принципу права він має сприйматися і національною правовою системою. Дотримання вимог принципу правової визначеності наблизить українське законодавство до європейських правових стандартів, сприятиме вдосконаленню механізмів правотворчості та правореалізації, слугуватиме додатковою гарантією захищеності людини від свавілля органів державної влади.

Ключові слова: принцип права, верховенство права, принцип правової визначеності, адміністративне судочинство. 


\section{Summary}

Smokovych M. I. The principle of legal certainty in administrative proceedings: some theoretical principles and practical application. - Article.

The article examines some theoretical principles and practical application of the principle of legal certainty in administrative proceedings. It is stated that the principle of legal certainty generalizes to such general legal categories as "inviolability of rights", "quality and accuracy of law", "stability and finality of court decisions", "legitimate expectations", on which the case law of the European Court of Human Rights is based, as well as the practice of the Supreme Court. It is stated that predictability is the basis of one of the fundamental and fundamental for the implementation, protection of the rights and interests of every person - the principle of legal certainty, which, in turn, is one of the principles of the rule of law, and the guiding principle in responsibilities and powers. It was stated that our national justice is still on the way to the implementation of generally accepted European criteria of a fair trial.

It is concluded that legal certainty is a universal legal principle, the effect of which extends to such important areas of legal relations between the state and the individual as the realization and protection of human and civil rights and freedoms, establishing legal responsibility, grounds and procedure for inadmissibility, inadmissibility, aimed at unjustified restriction of human rights and freedoms, establishing the proportionality of the restrictions applied to the person, the exercise of powers by public authorities within the limits set by the Constitution and laws of Ukraine.

It is stated that the principle of legal certainty is one of the basic principles of European law and is often used in the case law of the Court of Justice and the European Court of Human Rights. In the status of a general principle of law, it must be perceived by the national legal system. Compliance with the requirements of the principle of legal certainty will bring Ukrainian legislation closer to European legal standards, will improve the mechanisms of lawmaking and law enforcement, will serve as an additional guarantee of human protection from arbitrariness of public authorities.

Key words: principle of law, rule of law, principle of legal certainty, administrative proceedings. 